\title{
EXPRESSION OF RABBIT CYTOCHROME P-45OIIE2 IN YEAST AND STABILIZATION OF THE ENZYME BY 4-METHYLPYRAZOLE
}

\author{
Steven J. Pernecky, Todd D. Porter, and Minor J. Coon \\ Department of Biological Chemistry, Medical School, \\ The University of Michigan, Ann Arbor, MI 48109
}

Received October 3, 1990

SUMMARY: A rabbit cytochrome P-450llE2 full-length CDNA was cloned into a yeast episomal plasmid (YEp13) between the copper-responsive yeast metallothionein gene promoter (CUP1) and the iso-1-cytochrome $c$ gene terminator (CYC1), and the cytochrome P-450 was expressed in Saccharomyces cerevisiae. The microsomal fraction prepared from copper-treated cells exhibited a ferrous carbonyl difference spectrum with an absorption maximum at $451 \mathrm{~nm}$ and contained approximately 0.07 $\mathrm{nmol}$ of P-450llE2 per $\mathrm{mg}$ of protein. The P-450llE2 protein expressed in yeast microsomes was catalytically competent as judged by the NADPH-dependent deethylation of $\mathrm{N}$-nitrosodiethylamine and by the oxidation of butanol. Cholate solubilization and polyethylene glycol fractionation of yeast microsomal P-450IIE2 yielded a preparation with a markedly lower specific content than that of intact microsomes, but, when 4-methylpyrazole was included during solubilization, the holoenzyme was completely stabilized.

(9) 1990 Academic Press, Inc.

P-450 cytochromes catalyze the biotransformation of numerous structurally unrelated drugs and environmental toxicants in addition to endobiotics such as steroids and fatty acids (1). The metabolism of this broad spectrum of compounds is brought about by a superfamily of distinct P-450 gene products (2) that catalyze diverse and sometimes overlapping reactions (1). The role of individual P-450 isozymes in metabolism has been determined by purification and characterization in reconstituted systems, and heterologous expression of P-450 CDNAs has additionally permitted the characterization of previously unidentified forms and variants $(3,4)$. Heterologous expression has also provided a useful approach when the homogeneity of a purified preparation was in question (5).

The P-450llE gene subfamily in the rabbit has two members $(6,7)$. The IIE1 gene encodes an ethanol-inducible cytochrome ( $\mathrm{P}-450$ form $3 \mathrm{a}$ ), which was originally purified from liver microsomes of rabbits treated with ethanol (8) and has recently been cloned and expressed in Saccharomyces cerevisiae (9). The IIE1 protein catalyzes the oxidation of alcohols, nitrosamines, ethers, and aromatic compounds such as acetaminophen and $p$-nitrophenol, in addition to the reductive cleavage of hydroperoxides $(10,11)$. The related P-450IIE2 gene encodes a protein (designated

The following abbreviations are used: PEG, polyethylene glycol 8000; NDEA, $\mathrm{N}$-nitrosodiethylamine; and PMSF, phenylmethylsulfonyl fluoride. 
P-450 form 3d) that differs from IIE1 in only 16 amino acid residues scattered throughout the protein (7), and which has not yet been isolated from liver microsomes of adult rabbits. Nevertheless, IIE2 expression is indicated by the presence of the corresponding mRNA in the adult rabbit liver, where it is present at half the level of the IIE1 transcript $(7,12)$. Moreover, Bonfils et al. (13) have reported that the principal P-450 species present in two-week old rabbits appears to be P-450IIE2, as determined by $\mathrm{N}$-terminal sequence analysis and immunological cross-reactivity with P-450lIE1 antibodies. Liver microsomal immunoreactive P-450IIE protein is increased during development $(13,14)$ and following administration of a number of diverse agents, including ethanol $(12,15)$. However, while inhibitory antibodies to IIE1 have been useful in determining the contribution of the IIE cytochromes to liver microsomal xenobiotic metabolism, it has not been possible to determine the extent to which IIE1 and IIE2 individually participate in these reactions.

To facilitate the characterization of P-450IIE2 and the comparison of its biophysical and biochemical properties to those of P-450IIE1, a P-450IIE2 CDNA was isolated from a rabbit liver cDNA library (16), cloned into a yeast episomal plasmid containing the copper-inducible promoter of the yeast metallothionein gene (17), and expressed in $S$. cerevisiae. The IIE2 protein is located in the yeast microsomal fraction and metabolizes typical IIE1 substrates. Interestingly, detergent solubilization of yeast microsomes converts P-450IIE2 (but not IIE1) to inactive P-420; however, full catalytic activity is preserved if solubilization and fractionation are carried out in the presence of 4-methylpyrazole.

\section{METHODS}

Construction of Yeast Expression Plasmid Containing P-450llE2. A 1.4-kb cDNA, isolated from a rabbit liver cDNA library (18), was found to contain $82 \%$ of the coding region of the P-450llE2 gene, beginning at nucleotide 305 (see Ref. 6 for base pair numbering), as previously reported (16). The partial IIE2 CDNA sequence was identical to the exonic sequence of the IIE2 gene except for two $A$ for $T$ base substitutions that result in two amino acid replacements ( $P \mathrm{Phe}_{165}$ to $\| \mathrm{le}$ and $\mathrm{Leu}_{268}$ to $\mathrm{Gln}$ ). The 280-bp Nco1-Xmn1 fragment encoding the N-terminal region of P-450llE1 was ligated to the partial IIE2 CDNA at a common Xmn1 site to obtain a full-length chimeric clone. Oligonucleotide-directed mutagenesis with the Bio-Rad mutagene $\mathrm{R}^{\mathrm{M}} 13$ mutagenesis kit was used to change three nucleotides in the IIE1 portion of the clone and the two nucleotides indicated above in the IIE2 fragment such that the full-length P-450lIE2 clone would code for a protein identical to that encoded by the P-450llE2 gene. An Xho1 linker was then added to the $3^{\prime}$-nontranslated end of the full-length cDNA, and the P-450IIE1 portion of the YEp3a yeast expression vector (9) was replaced with the IIE2 CDNA construct. The resulting plasmid was designated YEp3d. The $50 . L 4$ strain of $S$. cerevisiae, yeast cell transformation, growth conditions, copper induction of expression, and preparation of microsomal fractions were as previously described (9).

Detergent Solubilization of Yeast Microsomes. Yeast microsomes (100 to $200 \mathrm{mg}$ of protein at a final concentration of $2 \mathrm{mg} / \mathrm{ml}$ ) were solubilized with cholate $(5 \mathrm{mg} \mathrm{per} \mathrm{mg}$ of protein) and $0.2 \%$ Tergitol NP-10 (final concentration) in $0.1 \mathrm{M}$ Tris-OAc buffer, $\mathrm{pH} 7.4$, containing $20 \%$ glycerol, $0.1 \mathrm{M} \mathrm{KCl}$ and $1 \mathrm{mM}$ EDTA. PEG was added to $6 \%$, the mixture was centrifuged at low speed, the resultant supernate was made $16 \%$ in PEG, and the precipitate was collected by centrifugation. The pellet was suspended in $0.1 \mathrm{M}$ potassium phosphate buffer, $\mathrm{pH} 7.4$, containing $20 \%$ glycerol and $1 \mathrm{mM}$ EDTA, and dialyzed overnight at $4^{\circ} \mathrm{C}$. When present, 4-methylpyrazole was $50 \mu \mathrm{M}$ in solubilization and dialysis buffers. 
Measurement of P-450 Monooxygenase Activity, CO reactivity of P-450, and Binding of 4-Methyloyrazole to P-450llE2. The activity of the expressed cytochrome was assayed with $0.05 \mathrm{nmol}$ of P-450, $1.0 \mathrm{nmol}$ of NADPH-cytochrome P-450 reductase, and $30 \mu \mathrm{mol}$ of butanol or NDEA $(2 \mu \mathrm{mol}$ with intact microsomes or $100 \mu \mathrm{mol}$ with solubilized preparations) in a $1.0-\mathrm{ml}$ reaction mixture containing $50 \mathrm{mM}$ potassium phosphate buffer, $\mathrm{pH}$ 7.4. In addition, solubilized preparations were supplemented with $30 \mu \mathrm{g}$ of dilauroylglyceryl-3-phosphorylcholine per ml. NADPH $(1 \mathrm{mM})$ was added to initiate the reaction, which was conducted at $37^{\circ} \mathrm{C}$ in $3-\mathrm{ml}$ septum-sealed vials for $30 \mathrm{~min}$. Assay conditions for measuring NDEA N-deethylation and butanol oxidation were as previously described $(19,20)$. Spectral determinations with intact microsomes were made with a Perkin-Elmer lambda 6 UV/VIS spectrophotometer, whereas with the solubilized preparations a Varian Cary 219 UV/VIS spectrophotometer was used. Yeast microsomal preparations were diluted to a final concentration of $7.5 \mathrm{mg}$ of protein $/ \mathrm{ml}$ (intact microsomes) or $2 \mathrm{mg}$ of protein/ml (PEG-fractionated preparations) with $150 \mathrm{mM}$ potassium phosphate buffer, pH 7.4, containing 20\% glycerol, and $1 \mathrm{mM}$ EDTA for spectral analysis. The P-450 content was determined from the absorbance difference between 452 and $490 \mathrm{~nm}$ of the ferrous carbonyl derivative with an absorption coefficient of $80 \mathrm{mM}^{-1}$ as previously established for IIE1(8). For spectral assay of 4-methylpyrazole binding to P-450llE2, yeast microsomes were diluted to $7.5 \mathrm{mg}$ of protein $/ \mathrm{ml}$ in $50 \mathrm{mM}$ potassium phosphate buffer, $\mathrm{pH}$ 7.6. Aliquots of concentrated 4-methylpyrazole solutions and equal volumes of water were added to the sample and reference cuvettes, respectively. The total volume increase was less than $5 \%$. Protein content was determined by the Pierce BCA method (21), and immunoreactivity was determined with polyclonal antibodies raised to P-450 form $3 a(20)$.

\section{RESULTS AND DISCUSSION}

Copper-Inducible Expression of P-450IIE2 in S. cerevisiae. A full-length P-450IIE2 CDNA identical to that encoded by the IIE2 gene was constructed from the 5 ' end of a IIE1 CDNA and a previously isolated partial IIE2 CDNA (16) and inserted between the copper-responsive yeast metallothionein gene promoter (CUP1) and the iso-1cytochrome $c$ gene terminator (CYC1) in YEp13. The CO difference spectrum of microsomes from copper-treated cells transformed with the YEp13 vector had only very slight absorption in the $450-\mathrm{nm}$ region, as shown in Fig. 1, indicating negligible expression of endogenous cytochrome P-450. In contrast, a prominent absorption peak at $451 \mathrm{~nm}$ was evident with microsomes from copper-treated cells transformed with YEp3d, reflecting the expression of intact P-450llE2. The specific content of typical P-450llE2-containing yeast microsomal preparations was about $0.07 \mathrm{nmol}$ of P-450 per $\mathrm{mg}$ of protein. Electrophoresis and subsequent immunoblot analysis of yeast microsomal proteins showed that P-450llE2 is recognized by polyclonal antibody raised to P-450liE1 (results not shown), and that the expressed cytochrome has the same mobility as heterologously expressed IIE1 (9), indicating a molecular weight consistent with that expected for the protein encoded by the P-450llE2 gene (7).

Catalytic Activity of Expressed P-450IIE2. Recently, rabbit P-450llE1 expressed in yeast microsomes was found to catalyze the $\mathrm{N}$-deethylation of NDEA ( 9 ) and to require added NADPH-cytochrome P-450 reductase for activity. P-450llE2 similarly expressed was examined for deethylase activity and found to catalyze this reaction at a rate similar to that of expressed P-450IIE1, but somewhat less than the rate obtained with purified rabbit liver enzyme $(9,19)$. The lower activity may be due to incomplete incorporation of exogenous reductase into these microsomal membranes. Enzymatic activity was 
dependent upon exogenously added reductase, NADPH, and substrate, and negligible amounts of product were formed when microsomes from cells containing the YEp13 vector were used, indicating that the P-450IIE2 expressed in yeast microsomes is the catalyst in the nitrosamine deethylation reaction. The linearity of product formation over a 30-min time course at $37^{\circ} \mathrm{C}$ indicated that IIE2 expressed in yeast microsomes is not inactivated during NADPH-supported nitrosamine metabolism. In results not presented, expressed IIE2, like purified hepatic P-450IIE1 (22), was shown to catalyze the oxidation of butanol to butyraldehyde.

Stabilization of Solubilized P-450llE2 Expressed in Yeast. Yeast microsomes containing P-450llE2 were solubilized with cholate and fractionated with PEG in preparation for chromatographic separation of the cytochrome from other yeast microsomal proteins. However, the P-450 content of the 6 to $16 \%$ pellet determined from the CO-ferrous difference spectrum, as presented in Fig. 2, was only about one-third of the expected value. These results are in sharp contrast to the finding that IIE1, when expressed in yeast and solubilized in a similar manner, yields a preparation whose specific content is identical to that of intact microsomes. The low specific content of the P-450IIE2 preparation at least partly reflects a conversion of P-450 to P-420, as presented in Fig. 2. Attempts to improve the recovery of P-450IIE2 in the PEG fraction by including the protease inhibitor PMSF $(1 \mathrm{mM})$ and dithiothreitol $(1 \mathrm{mM})$, or by omitting Tergitol in the solubilization buffer, were unsuccessful. The differential stability of the two
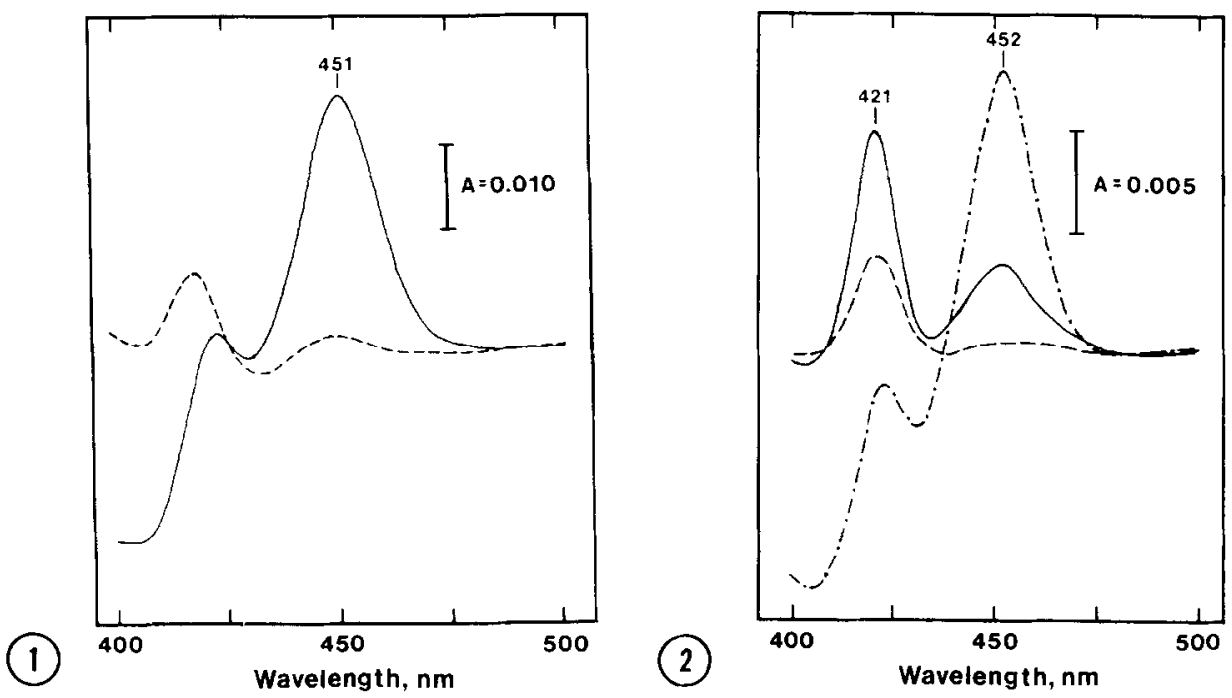

Fig. 1. Ferrous-carbonyl difference spectra of intact yeast microsomes. The dashed line represents the preparation from yeast containing the YEp13 vector, and the solid line represents the preparation containing expressed P450llE2.

Fig. 2. Ferrous-carbonyl difference spectra of cholate-solubilized and PEGfractionated yeast microsomes. The dashed line represents the preparation from yeast containing the YEp 13 vector (control), the solid line indicates the preparation containing IIE2, and the dot and dashed line represents the IIE2-containing microsomes solubilized and fractionated in the presence of 4-methylpyrazole. 
yeast microsomal P-450llE proteins to detergent solubilization provides an explanation for the success in purification of P-450llE1 from adult rabbit liver microsomes (8) and our inability to purify P-450IIE2 from the same source. Recently, a protein identical in the first $18 \mathrm{~N}$-terminal amino acids with that encoded by the P-450llE2 gene was purified from liver microsomes of neonatal rabbits (13). The low specific content of the purified preparation, which was at least partly attributable to the presence of a considerable amount of P-420, may be explained by the inherent instability of solubilized IIE2, as illustrated by the present studies.

A number of detergent-labile mitochondrial (23) and microsomal (24-26) forms of P-450 have been successfully purified in the presence of substrate, which presumably prevents destabilization by binding to the enzyme. Pyrazole is an alcohol dehydrogenase inhibitor that is both an inducer and a substrate for rat P-450llE1 (27). Recently, the 4-methyl derivative of pyrazole has been found to bind to rabbit P-450IIE1 with particularly high affinity (28). Therefore, 4-methylpyrazole was included in all buffers during solubilization of P-450IIE2 from yeast microsomes and in the suspension and dialysis buffers, in an attempt to prevent denaturation of the enzyme. The results, shown in Fig. 2 and Table I, demonstrate that the presence of 4-methylpyrazole during solubilization and fractionation increased the specific content of the expressed P-450 about threefold in the $16 \%$ PEG pellet, while markedly decreasing the amount of P-420. The NDEA deethylase activity of such preparations, expressed per mg of protein, was

Table I

P-450 Content and Catalytic Activity of Solubilized Yeast Microsomal Preparations: Effect of 4-Methylpyrazole

\begin{tabular}{|c|c|c|c|c|}
\hline \multirow{2}{*}{$\begin{array}{l}\text { Yeast } \\
\text { microsomal } \\
\text { preparation }^{a}\end{array}$} & \multirow{2}{*}{$\begin{array}{l}\text { 4-Methyl- } \\
\text { pyrazole } \\
\text { present } \\
\text { during } \\
\text { solubilization }\end{array}$} & \multirow{2}{*}{$\begin{array}{c}\text { Specific } \\
\text { content, } \\
\text { nmol P-450/ } \\
\text { mg protein }\end{array}$} & \multicolumn{2}{|c|}{ NDEA deethylation activity $b$} \\
\hline & & & $\underset{\mathrm{mg} \text { protein }}{\mathrm{pmol} \mathrm{C}_{2} \mathrm{H}_{4} / \mathrm{min} /}$ & $\begin{array}{c}\mathrm{nmol} \mathrm{C}_{2} \mathrm{H}_{4} / \mathrm{min} \\
\mathrm{nmol}^{-} \mathrm{P}-450\end{array}$ \\
\hline
\end{tabular}

$\begin{array}{lllll}\text { P-450llE1 } & - & 0.13 & 11.0 & 0.08\end{array}$

P-450IIE2

0.03

1.6

0.05

"

0.08

3.6

0.05

\footnotetext{
${ }^{a}$ The P-450 content of IIE1 or IIE2 expressed in intact yeast microsomes was 0.12 and $0.08 \mathrm{nmol} / \mathrm{mg}$ protein, respectively.

The deethylation of NDEA yields ethylene, which was determined because of the high sensitivity of the assay (19), as well as acetaldehyde, which is the major product. The total rate of deethylation is 9.3 times as great as measured by ethylene formation alone.
} 
enhanced more than twofold, as indicated in Table I. Since the inclusion of 4-methylpyrazole during solubilization of control microsomes yielded a preparation with no absorption peak in the 450-nm region of the CO-reduced difference spectrum, the increase in CO-reactive protein is due entirely to an increase in the specific content of IIE2. Furthermore, addition of 4-methylpyrazole to the reaction mixtures did not affect the specific content or catalytic activity. Hence, the effect of 4-methylpyrazole is not due to an alteration in the absorption coefficient of the ferrous carbonyl derivative or a stimulation of the catalytic activity of the solubilized P-450IIE2.

Preliminary experiments were conducted to determine if 4-methylpyrazole binds to oxidized P-450IIE2 in yeast microsomes. The results depicted in Fig. 3 demonstrate that the interaction of 4-methylpyrazole with P-450IIE2 elicits a type II binding spectrum with a peak at $427 \mathrm{~nm}$ and a trough at $394 \mathrm{~nm}$. A difference spectrum was not observed, however, when microsomes from cells containing the YEp13 vector were assayed. The present evidence suggests that ligand binding preserves the native conformation of the IIE2 during detergent solubilization. The demonstration here of a protective effect of 4-methylpyrazole on P-450IIE2 offers a promising approach to purification of this

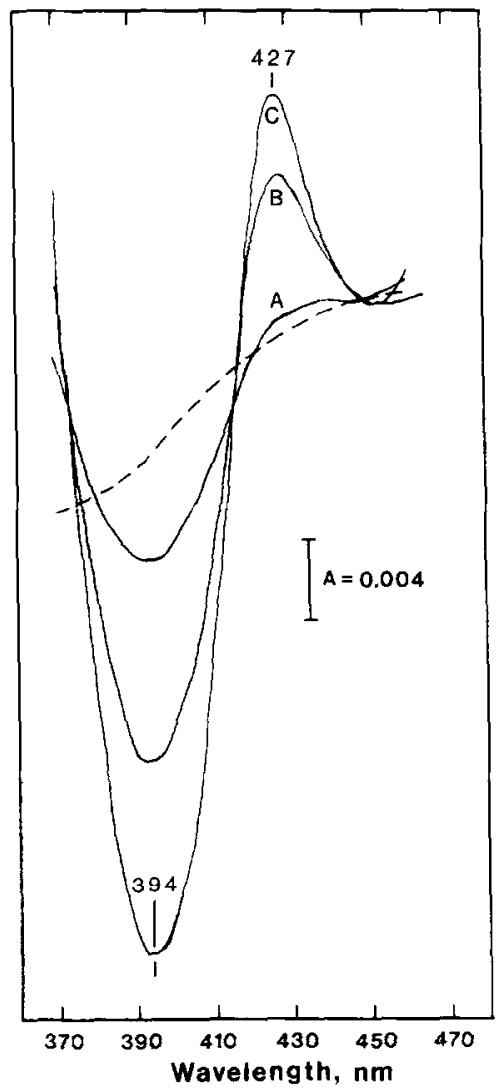

Fig. 3. Binding of 4-methylpyrazole to yeast microsomal P-450IIE2. The solid lines are traces for IIE2 yeast microsomes determined in the presence of various concentrations of 4-methylpyrazole $(\mathrm{A}=0.5 \mu \mathrm{M}, \mathrm{B}=5.0 \mu \mathrm{M}, \mathrm{C}=50 \mu \mathrm{M})$. The dashed line is a trace for YEp13 vector microsomes determined in the presence of $\frac{50 \mu \mathrm{M}}{4-\mathrm{m}}$ 4-methylpyrazole. 
cytochrome from adult and neonatal rabbit liver microsomes, as well as from yeast microsomes.

ACKNOWLEDGMENTS: We are grateful to Dr. Dennis R. Koop, Case Western Reserve University School of Medicine, for helpful discussions. This research was supported by Grant AA-06221 from the National Institute for Alcohol Abuse and Alcoholism, National Institutes of Health.

\section{REFERENCES}

1. Black, S.D., and Coon, M.J. (1987) Adv. Enzymol. Relat. Areas Mol. Biol. 60, 3587.

2. Nebert, D.W., Nelson, D.R., Adesnik, M., Coon, M.J., Estabrook, R.W., Gonzalez, F.J., Guengerich, F.P., Gunsalus, I.C., Johnson, E.F., Kemper, B., Levin, W., Philips, I.R., Sato, R., and Waterman, M.R. (1989) DNA 8, 1-13.

3. Kronbach, T., Larabee, T.M., and Johnson, E.F. (1989) Proc. Natl. Acad. Sci. USA 86, 8262-8265.

4. Matsunaga, E., Zanger, U.M., Hardwick, J.P., Gelboin, H.V., Meyer, U.A., and Gonzalez, F.J. (1989) Biochemistry 28, 7349-7355.

5. Hayashi, S., Morohashi, K., Yoshioka, H., Okuda, K., and Omura, T. (1988) J. Biochem. (Tokyo) 103, 858-862.

6. Khani, S.C., Porter, T.D., and Coon, M.J. (1988) Biochem. Biophys. Res. Commun. 150, 10-17.

7. Khani, S.C., Porter, T.D., Fujita, V.S., and Coon, M.J. (1988) J. Biol. Chem. 263, 7170-7175.

8. Koop, D.R., Morgan, E.T., Tarr, G.E., and Coon, M.J. (1982) J. Biol. Chem. 257, 8472-8480.

9. $\quad$ Fujita, V.S., Thiele, D.J., and Coon, M.J. (1990) DNA 9, 111-118.

10. Koop, D.R., and Coon, M.J. (1986) Alcohol. Clin. Exp. Res. 10, 44S-49S.

11. Vaz, A.D.N., Roberts, E.S., and Coon, M.J. (1990) Proc. Natl. Acad. Sci. USA 87 , 5499-5503.

12. Porter, T.D., Khani, S.C., and Coon, M.J. (1989) Mol. Pharmacol. 36, 61-65.

13. Bonfils, C., Combalbert, J., Pineau, T., Angevin, J., Larroque, C., Derancourt, J., Capony, J., and Maurel, P. (1990) Eur. J. Biochem. 188, 187-194.

14. Song, B., Gelboin, H.V., Park, S., Yang, C.S., and Gonzalez, F.J. (1986) J. Biol. Chem. 261, 16689-16697.

15. Koop, D.R., Crump, B.L., Nordblom, G.D., and Coon, M.J. (1985) Proc. Nat/. Acad. Sci. USA 82, 4065-4069.

16. Pernecky, S.J., Fujita, V.S., Thiele, D.J., Porter, T.D., and Coon, M.J. (1989) J. Cell Biol. 107, 193a.

17. Thiele, D.J., and Hamer, D.H. (1986) Mol. Cell. Biol. 6, 1158-1163.

18. Tukey, R.H., Okino, S., Barnes, H., Griffin, K.J., and Johnson, E.F. (1985) J. Biol. Chem. 260, 13347-13354.

19. Ding, X., and Coon, M.J. (1988) Drug Metab. Dispo. 16, 265-269.

20. Koop, D.R., Nordblom, G.D., and Coon, M.J. (1984) Arch. Biochem. Biophys. 235, 228-238.

21. Smith, P.K., Krohn, R.I., Hermanson, G.T., Mallia, A.K., Gartner, F.H., Provenzano, M.D., Fujimoto, E.K., Goeke, N.M., Olson, B.J., and Klenk, D.C. (1985) Anal. Biochem. 150, 76-85.

22. Morgan, E.T., Koop, D.R., and Coon, M.J. (1982) J. Biol. Chem. 257, 1395113957.

23. Takemori, S., Sato, H., Gomi, T., Suhara, K., and Katagiri, M. (1975) Biochem. Biophys. Res. Commun. 67, 1151-1157.

24. Kellis, Jr., J.T., and Vickery, L.E. (1987) J. Biol. Chem. 262, 4413-4420.

25. Kominami, S., Shinzawa, K., and Takemori, S. (1982) Biochem. Biophys. Res. Commun. 109, 916-921.

26. Juvonen, R.O., Shkumatov, V.M., and Lang, M.A. (1988) Eur. J. Biochem. 171, 205-211.

27. Clejan, L.A., Koop, D.R., and Cederbaum, A.I. (1989) Drug Metab. Dispos. 17, 694-698.

28. Koop, D.R. (1990) Chem. Res. Toxicol. 3, 377-383. 